DOI 10.26724 / 2079-8334-2017-3-61-108-114

UDC 616.071+ 616.379-008.64

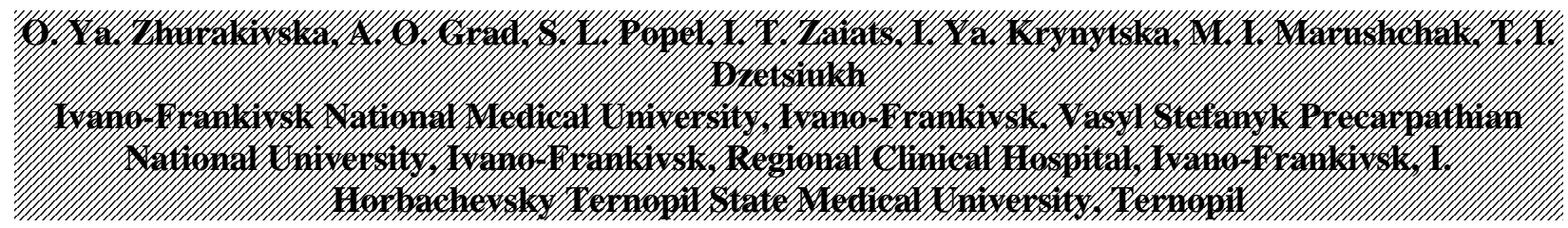

\title{
MORPHOLOGICAL AND FUNCTIONAL CHANGES OF MASTICATORY MUSCLE NEUROMUSCULAR JUNCTIONS IN THE LATER PERIODS OF STREPTOZOTOCIN DIABETES MELLITUS COURSE
}

e-mail: zhurakivska.o.ya@gmail.com

\begin{abstract}
The work is devoted to the study of morphofunctional changes of neuromuscular junctions (NMJ) and their hemocirculatory circulation in streptozotocin diabetes mellitus (SDM). Histological and electron microscopic methods of investigation were used. It was established that the SDM for 56-70 days of the course leads to the destruction of most NMJs, which is morphometrically expressed in the decrease of their area. In efferent preterminal nerve fibers, axonal atrophy occurs and partial degeneration of the myelin sheath. At the ultra-structural level, there is a violation of the fine architectonics of neuromuscular synapses, namely, a decrease in the area, the length of the synaptic contact, the number of synaptic vesicles, the number of folds of the postsynaptic membrane, and the distance between them. Such changes in NMJ occur on the background of the development of diabetic microangiopathy and, as a result, lead to a violation of the conductivity of nerve fibers in the masticatory muscle and the excitability of muscle fibers, as evidenced by the data of electroneuromyography of the ENMG. According to ENMG data, with the duration of experimental diabetes of 56-70 days, the axonal polyneuropathy was detected in 6 animals, the other 4 had an axonal-demyelinating polyneuropathy. In this case, only in $9.5 \%$ of cases the duration of the motor unit potentials decreases, but in $64.5 \%$ of cases the amplitude of the oscillations decreases $(\mathrm{p}<0.05)$, which indicates a rapid rate of destruction of NMJ in decompensated experimental DM.
\end{abstract}

Key words: neuromuscular junction, chewing muscle, streptozotocin diabetes mellitus.

The article is part of SRW "Age features of pathomorphogenesis of some organs of the neuroendocrine, cardiovascular, digestive and respiratory systems in diabetes mellitus" (State registration number 0116U003598).

The study of structural changes in organs and tissues in diabetes mellitus (DM) is one of the topical problems of modern medicine [26], because in different countries the number of patients with diabetes mellitus is $4-7 \%$ of the total population of patients and annually increases [10]. The sharp rise in incidence of disease, severe complications and high mortality, especially among working-age population has led to diabetes inclusion in the triad of today's most common disease (after cardiovascular diseases and cancer), which are the most common causes of morbidity and mortality of patients $[13,21]$. Therefore, DM is the most acute medical and social problem of the healthcare system of all countries in the world. [19, 20].

As for the study of the effect of hyperglycemia on the ultrastructural organization of neuromuscular synapses (NMS), we find such data only in the works of V. A. Levitsky and co-authors. [16] and N.Yu. Khachayants [14]. At hyperglycemia, they observed ruptures of nerve terminals, exposure of synaptic folds, and appearance of behind synaptic zones with little or no folds. Adaptation changes in neuromuscular junctions (NMJ) in this position are associated with lengthening and increasing the number of terminal branches of the motor axon [6]. At the same time, the number of terminal neurleulocytes, the cortical nuclei and the area of NMJ decreases [18]. According to some authors [17], the qualitative features of the restructuring of NMJ in the experimental streptotrozine DM should lead to the formation of unusual structures of active zones and a new histochemical characterization of the totality of NMJ in skeletal muscles at CD. However, these data remain at the level of hypotheses and assumptions, which makes such studies particularly relevant at the present stage of the development of morphological science.

The purpose of research was to examine the morpho-functional changes in the neuromuscular endings of the masticatory muscle in the late periods of experimental diabetes mellitus type 1.

Materials and methods. In the work were used 20 mature male rats of the Wistar line, which were divided equally into 2 groups: control and experimental. Experimental diabetes mellitus (EDM) in animals of the experimental group (EG) was modeled by a single intraperitoneal injection of streptozotocin (dissolved in $0.1 \mathrm{M}$ citrate buffer solution with $\mathrm{pH} 4.5$ ) at a dose of $6 \mathrm{mg}$ per $100 \mathrm{~g}$ of body weight. The control group (CG) of animals in an equivalent dose was injected intraperitoneally with $0.1 \mathrm{M}$ citrate buffer with $\mathrm{pH}$ 4.5. Euthanization of animals was performed under thiopental anesthesia by decapitation and subsequent collection of blood in a test tube for biochemical studies. 
The level of glucose was determined from a drop of blood of the caudal vein using test strips on a glucose meter of the company "Accu-Chec" (Germany). The level of glycosylated hemoglobin (HbA 1c) in the blood was determined in a certified "Diameb" laboratory using the ACCENT-200 HbA1c DIRECT diagnostic kit (PZ Cormay S.A., Poland).

The material for the study was a chewing muscle, which was taken on 56 and 70 days of experimental DM. For histological examination, the masticatory muscle was fixed in $12 \%$ neutral formalin, paraffin blocks were made, and the sections were stained with hematoxylin and eosin, by Hart. To detect neuromuscular junctions, the chewing muscles were fixed for 25-30 days in $12 \%$ neutral formalin. The material was washed and slices $30-40 \mu \mathrm{m}$ thick were made, which were processed by the Bilshowski-Gros method in a cryostat.

For the electron microscopic examination, pieces of material were fixed in a $2 \%$ solution of osmium tetrachloride, conducted and contrasted according to the generally accepted method. Ultra-thin sections were made which were studied under the electron microscope PEM-125 K at an accelerating voltage of $75 \mathrm{kV}$, followed by photography at magnifications from 1200 to 12000 times.

Histological preparations were studied under light microscope MS 300 (TXR) and photographed using a digital CCD camera (Industrial digital camera UHCCD05100KPA-U-NA-N-C-SQ-NA). Morphometry was performed on the specified photo material using the NIH USA "Image J" program in manual mode, taking into account the magnifications.

Stimulation and interference electroneuromyography (ENMG) was conducted on the computer neuro-electromyographic complex Neuro-EMG-Micro manufactured by Neurosoft (Russia). The speed of the pulse (PS), the amplitude and duration of the $\mathrm{F}$ wave, the amplitude, the latent period and the polyphase of the $\mathrm{M}$ wave were determined, and monosynaptic testing (H-reflex) was performed. According to the ENMG results, the percentage of the ratio Hmax / Mmax was calculated. The maximum PS for HB was determined by the formula: PS = S / (T2-T1) m / s; Where T1 is the latent period when the muscle is irritated at the distal point (c); T2 - latent period when muscle is irritated at the proximal point (c); $\mathrm{S}$ is the distance between the proximal and distal points of stimulation (m).

Computer processing of data was carried out using the statistical package Stat.Soft.Inc; Tulsa, OK, USA; Statistica 6

Results and their discussion. On the 56th day of the development of experimental DM, the level of glucose and HbA1C in the blood of rats grows at $19.85 \pm 2.62 \mathrm{mmol} / 1$ (control: $4.77 \pm 0.51 \mathrm{mmol} / \mathrm{L}$, $\mathrm{p}=0.0079$ ) and $10.51 \pm 1.07 \%$ (control: $1.79 \pm 0.47 \mathrm{mmol} / \mathrm{L}, \mathrm{p}=0.0079$ ).

On the 56th day of the experimental DM, most of the NMJ undergo destruction. At impregnation by Bolshivsky-Gros is found primitive form of thin terminals, which should be attributed to the so-called secondary branches of motor axons. Their area is $154.62 \pm 7.12 \mu \mathrm{m} 2$, which is $59.9 \%$ less than the control indicators (control - $385.81 \pm 12.42, \mathrm{p}<0.01$ ).

Data on the morphometric changes in NMS (Table 1) indicate that: their area, the length of the synaptic contact, the number of folds along the behind synaptic membrane decreases and the distance between them increases. This reduces the length of a single fold. The number of synaptic vesicles increases by $48.5 \%$.

Table 1

Histometric characteristics of neuromuscular synapses of muscle fibers of the masticatory muscle in experimental diabetes mellitus

\begin{tabular}{|c|c|c|c|c|}
\hline Term of experiment & \multicolumn{2}{|c|}{56 days } & \multicolumn{2}{c|}{70 days } \\
\hline Structural elements and their parameters & CG & EG & CG & EG \\
\hline Area of the neuromuscular synapse, $\mu \mathrm{m} 2$ & $7,43 \pm 0,72$ & $5,04 \pm 0,23^{\# \#}$ & $7,52 \pm 0,32$ & $4,82 \pm 0,49^{\# \#}$ \\
\hline Length of synaptic contact, $\mu \mathrm{m}$ & $2,69 \pm 0,28$ & $1,18 \pm 0,03^{\# \#}$ & $2,39 \pm 0,21$ & $1,23 \pm 0,16^{\# \#}$ \\
\hline Number of folds of postsynaptic membrane & $11,9 \pm 1,79$ & $6,5 \pm 0,81^{\# \#}$ & $11,7 \pm 1,95$ & $5,1 \pm 0,77^{* \# \#}$ \\
\hline Distance between folds, microns & $0,30 \pm 0,001$ & $0,50 \pm 0,002^{\#}$ & $0,26 \pm 0,003$ & $0,48 \pm 0,008^{\#}$ \\
\hline Length of a separate fold, microns & $2,78 \pm 0,06$ & $1,64 \pm 0,12^{\#}$ & $2,91 \pm 0,11$ & $1,09 \pm 0,07 * \# \#$ \\
\hline Number of synaptic vesicles & $166,4 \pm 12,22$ & $80,0 \pm 7,52^{\# \#}$ & $158,8 \pm 10,52$ & $82,4 \pm 7,18^{\# \#}$ \\
\hline
\end{tabular}

Notes: * $\mathrm{p}<0.05$; ** $\mathrm{p}<0.01$ - probability of indicators in comparison with the previous term of the experiment; \# $\mathrm{p}<0.05$; \#\# $\mathrm{p}$ $<0.01$ - the probability of the indicators compared with the control group.

From the side of intramuscular efferent fibers, especially their preterminal sections, massive atrophy of axons and significant disintegration of the myelin sheath were observed (Fig. 1a). The electron-optical density of axoplasm in atrophic axons is sharply reduced. Only single neurofilaments are detected, microtubules are absent. Mitochondria decrease in size, their matrix is compacted, and the outer membrane undergoes destruction and loses its continuity (Fig. 1b). 
In this term of experiment the electromyographic picture is mainly represented by fibrillation potentials and positive acute waves, including high-amplitude ones. At the same time, the average normalized duration of potentials of motor units (PMU) decreases to $89.5 \%$ (control $-110.7 \%, \mathrm{p}<0.05$ ).
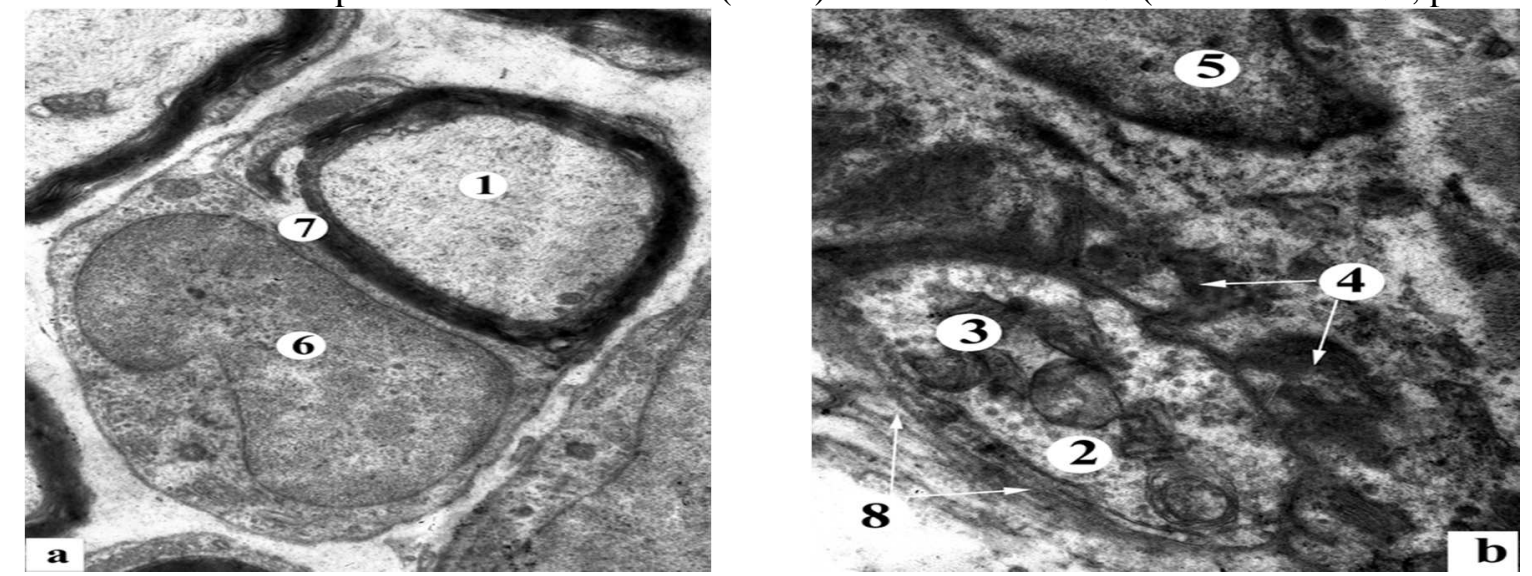

Fig. 1. Edema and stratification of the myelin sheath of efferent nerve fibers (a) and reorganization of the neuromuscular synapse of the masticatory muscle on day 56 from the start of modeling of streptozotocin diabetes mellitus. Electronic microphotographs. Sat: a) 9600 b) 16000. Markings: 1 - axon, 2 - axoplasm from synaptic vesicles, 3 - mitochondria, 4 - zasinaptic folds, 5 - nucleus of muscle fiber, 6 nucleus of neurolemocyte, 7 - lamellar lamellar myelin, 8 - outgrowths of terminal neurolemocyte.

On the 70th day of development of experimental DM, the level of glucose and HbA1C in the blood of rats remain high and amount to $21.09 \pm 3.64 \mathrm{mmol} / 1$ (control $-5.19 \pm 1.06 \mathrm{mmol} / \mathrm{L}, \mathrm{p}=$ 0.0079 ) and $1277 \pm 0.91 \%$ (control: $1.86 \pm 3.64 \mathrm{mmol} / \mathrm{L}, \mathrm{p}=0.0079$ ). In this period of observation there is a further destruction of NMJ. When impregnating for Bilshovsky-Gros, a decrease in the cofusion of myelinated nerve fibers and their varicose dilatation is observed (Fig. 2).

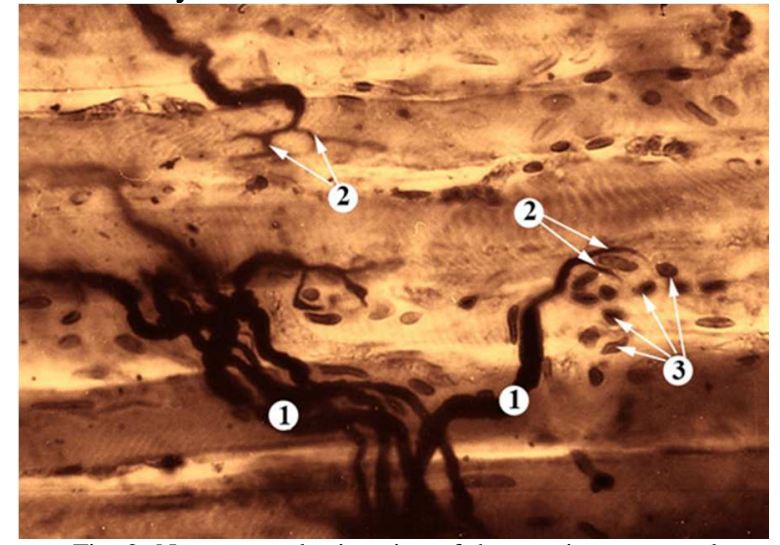

Fig. 2. Neuromuscular junction of the masticatory muscle on the 70th day of the course of experimental diabetes mellitus. Impregnation for Bilshovsky-Gros. Sat: about. 7, approx. 40. Markings: 1 - myelin nerve fibers, 2 - terminal axons; 3 nuclei of neuromecytes.

Their area is $139.13 \pm 12.17 \mu \mathrm{m} 2$, which is $64.0 \%$ less than the control indicators (control $386.19 \pm 14.89, \mathrm{p}<0.01)$. In the area of terminal branches, there are numerous nuclei of neurleulocytes (see Fig. 2).

Among the intramuscular efferent nerve fibers, there are initial signs of segmental demyelination. In electron microscopic examination, the edema and vacuolization of the cytoplasm of the neurolemocyte can be traced in the final myelinic nerve fibers, the space is expanded by the periaxal space, the degree of aggregation of the filamentous-tubular elements of the axoplasm increases, the myelin sheath is sinuous, and has areas of edema and lamination of the myelin plates (Fig. 3a).

In electron microscope studies, the axonplasm is severely depleted, the number of neurofilamentes decreases with the absence of microtubules in destructurization to axons (Fig. 3b).
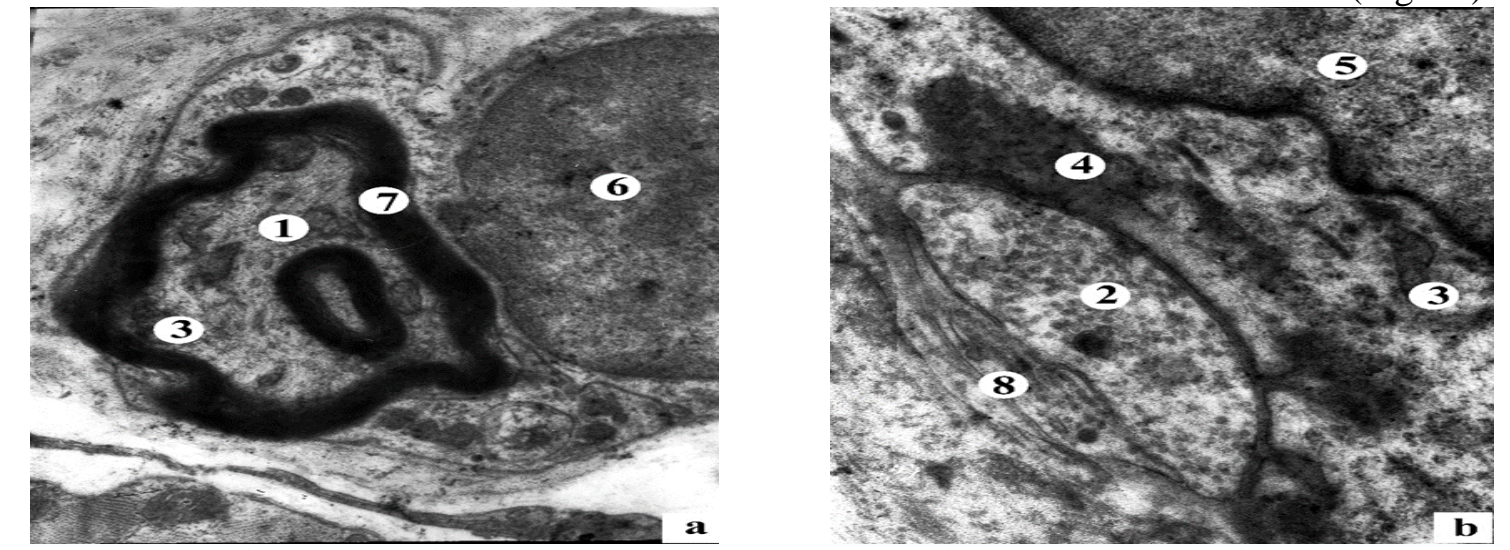

Fig. 3. destruction of myelin nerve fibers (a) and neuromuscular synapse (b) of the chewing muscles of rats on the 70th day of streptozotocin diabetes mellitus. Electronograms. Sat: a) 1200 b) 16000. Markings: 1 - axon, 2 - axoplasm with synaptic vesicles, 3 mitochondria, 4 - postsynaptic folds, 5 - nucleus of muscle fibers, 6 - nucleus of neurolemocyte, 7 - myelin, and 8 - processes of terminal neurolemocyte. 
Mitochondria are reduced in size, with an enlightened matrix and a destroyed inner membrane. Sometimes there is a pronounced destruction of the terminal branches of axons, in which the presynaptic pole is in the form of separate components of axoplasmic contacts.

As in the previous observation period, the morphometric changes (see Table 1) indicate a decrease in the area of the NMS, the length of the synaptic contact, and the number of folds of the postsynaptic membrane. Compared with the control group, an increase of 2.5 times the distance between the folds of the postsynaptic membrane, with a decrease in the length of the individual fold, is observed. The number of synaptic vesicles also decreases by $52.1 \%(\mathrm{p}<0.05)$.

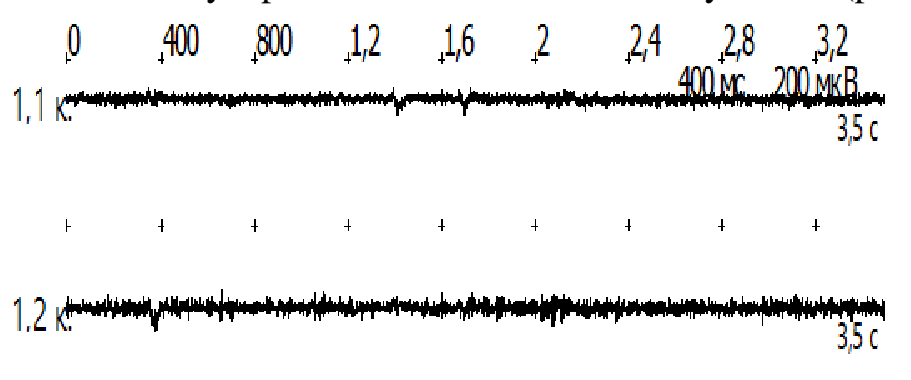

Fig. 4. Electroneuromyographic curve on the 70th day from the start of modeling of streptozotocin diabetes mellitus.

Such morpho-functional changes in NMS occur on the background of the development of diabetic microangiopathy. The main quantitative sign of the restructuring of the hemocirculatory circulation channel for 56-70 days of the course of experimental diabetes is a significant decrease in the area of the arterioles and capillaries clearance, in comparison with the control values (in all cases, $p$ $<0.05)$. This is accompanied by a probable increase in the area of the arteriolar wall, capillaries and venules (in comparison with the control values) surrounding the NMJ (in all cases, $\mathrm{p}<0.05$ ). There is a change in the diameters of hemocapillaries towards the increase in the number of vessels of small diameter, the size of loops of the intramuscular hemocapillary grid grows, and feeds the NMJ. Such changes in angioarhitectonics result in a decrease in the number of hemocapillaries by 56 days to $2.3 \pm$ 0.11 (control $-3.9 \pm 0.33, p=0.0064$ ) for 70 days to $2.1 \pm 0.15$ (control $-3.7 \pm 0.11, p=0.0064$ ), which belong to one NMS and provide its vascularization. Along with vasoconstriction by $16,7 \%$, the length of hemocapillaries in a radius of 30 microns from NMJ increases. However, in the radius of 5-10 microns, their number decreases sharply (by $41.0 \%, \mathrm{p}<0.01$ ), therefore, in the absence of hemocapillaries in their region, NMJ undergo degenerative changes and degradation.

In the area of NMJ, the walls of arterioles have a deformed contour due to narrowing and extensions of the lumen of varying lengths. In this case, the expansions have different shapes and sizes and can be single, multiple dispersed or grouped. Such changes are more common in arterioles, in which only fragments of the inner elastic membrane are detected. It should be noted that most of all narrow down those arterioles and hemocapillaries, next to the wall of which are the labrocytes.

Part of the blood capillaries is reduced; there are avascular or small vascular zones. The lumen of the hemocapillaries and venules sharply decreases, their walls are deformed, and the orientation of the vessels relative to the muscle bundles is disturbed.

At electron microscopic examination of blood microvessels, polymorphic changes were found.

In arterioles and venules, an increase in the electronic density of cytoplasm of endotheliocytes is observed. But in most hemocapillaries there is a decrease in the electron density of the necleoplasma and cytoplasm. Characteristically is the presence of microvascular microtromes in the lumen of microthrombi and erythrocyte sludges and a heterogeneous population of mitochondria in the cytoplasm of endotheliocytes. In some of them, there is a decrease in the electron-optical density of the matrix and crystallization of fragmentation, while in others it is diffuse homogenization.

The lumen surface of the endothelial cells has a rich microrelief. In individual hemocapillary, microclasmatosis is observed, in others, desquamation of endotheliocytes and exposure of the basal membrane. In rare capillaries the wall breaks down. The basal membrane loses its uniformity and a threelayer structure and is considerably thickened. The cytoplasm of pericytes contains a large number of dilated endoplasmic reticulum cages and vacuolated mitochondria. In capillary spaces, a large number of collagen fibers and active fibroblasts are observed which indicates the signs of capillarosclerosis and is one of the pathomorphological signs of diabetic microangiopathy. 
According to a number of authors $[4,12,25]$ at DM, the function of the synaptic apparatus of skeletal muscles is disrupted. In this case, the leading damaging agent is considered to be autoantibodies to the potential-dependent $\mathrm{Ca} 2+$ channels on the presynaptic membrane of NMJ.

It is known that for their efficient functioning a sufficient amount of energy material is needed. However, due to insulin resistance of membranes in DM and insulin deficiency in neurons and muscle fibers, acute glucose deficiency is observed [24] and as a result - difficulties in the synthesis and isolation of the synaptic mediator acetylcholine from axon terminals. At the same time, the function of the peripheral nervous apparatus of muscle fibers changes with the corresponding clinical and EMG manifestations in the form of muscle weakness, hypo-reflexion, and disturbances in the frequencyamplitude characteristics of muscle oscillations [9].

We show not only the morphological substrate of these changes in the ESDM, but also the EMGindicators of neuro-myopathy recorded in parallel, which testify in favor of this mechanism of its development. Many authors found that the chemical composition of skeletal muscles in DM is characterized by a decrease in the content of the main electrolytes. It is known that even minor changes in the water-salt balance reflect the nature of the excitability and conductivity of MNF [5, 22, 23]. These data are confirmed by the results of our study, manifested in the form of a decrease in amplitude and an increase in the latent period of the $\mathrm{F}$ wave. Changes in the electrical excitability of the masticatory muscle are due, in our opinion, to the changes in the blood supply of the NMJ, which are especially pronounced at 8 weeks from the start of the ESDM modeling and are confirmed by the data of other authors $[17,23]$. This clearly affects the nature of the ENMG: alongside a decrease in the amplitude of the M-response, the amplitude of the F-wave is statistically significantly reduced, but its polyphase and the latency period increase. At the same time, the SP is down by $79.3 \%$. This pattern confirms the activity of demyelination, as it is observed in other demyelinating diseases and testifies to a deep morphofunctional rearrangement of neural conductors by the type of segmental demyelination [7]. It should be noted that demyelination is characterized by a morphological sign of ESDM of any genesis $[2,8,15]$ and underlies convulsions $[1,3]$.

\section{Experim}

Experimental diabetes on day 56-70 leads to the destruction of most of the NMJ, which is morphometrically expressed in a decrease in their area. In efferent preterminal nerve fibers, axon atrophy occurs and partial degeneration of the myelin sheath. At the ultrastructural level, there is a violation of the fine architectonics of NMJ, namely, a decrease in the area, the length of the synaptic contact, the number of synaptic vesicles, the number of folds of the synaptic membrane and the distance between them. Such changes in NMJ occur on the background of the development of diabetic microangiopathy and, as a result, lead to a disruption of nerve fiber conduction in the masticatory muscle and excitability of muscle fibers, as evidenced by ENMG data. According to ENMG data, with the duration of experimental diabetes of 56-70 days, axonal polyneuropathy was detected in 6 animals, the remaining 4 had axonal-demyelinating polyneuropathy. In this case, only in $9.5 \%$ of cases the duration of the motor unit potentials decreases, but in $64.5 \%$ of cases the amplitude of the oscillations decreases $(p<0.05)$, which indicates a rapid rate of destruction of the NMJ in decompensated experimental DM.

Prospects for further research. Promising are further complex studies of changes in the NMJ, muscle fibers and hemomycirculatory channel of the masticatory muscle with streptozotocin diabetes mellitus, which will become the theoretical basis for the development and pathogenic justification of measures aimed at correcting and preventing the development of diabetic myopathy.

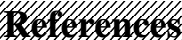

1.Andersen S. E. Osmotic demyelination syndrome in Addison crisis and severe hyponatremia / S. E. Andersen, B. StausbølGrøn, T. B. Rasmussen // Ugeskr. Laeger. - 2008. - Vol. 170, № 50. - P. 41-42.

2. Alifirova V. M. Modern approaches in the early diagnosis of diabetic neuropathy / V. M. Alifirova, R. B. Tsyrenzhapova, V. A. Stolyarova // Siberian Medical Journal. - 2011. - Vol. 26, No. 4. - P. 28-35.

3. Baslow M. H. Dynamic relationship between neurostimulation and $\mathrm{N}$-acetylaspartate metabolism in the human visual cortex: Evidence that NAA functions as a molecular water pump during visual stimulation / M. H. Baslow, J. Hrabe, D. N. Guilfoyle // J. Mol. Neurosci. - 2007. - Vol.32, № 8. - P. 235-245.

4.Bogacheva P. O. Mechanisms of $\mathrm{Ca} 2+$-dependent suppression of the mediator secretion in neo-neuromuscular neuromuscular synapses of the mouse: autoref.: Specialty 03.00.13 Normal physiology / P. O. Bogacheva // - M., - 2009. 19 p.

5.Costill D. L. Muscle water and electrolytes following varied levels of dehydration in man / D. L. Costill, R. Cote, W. Fink // J. Appl. Physiol. - 2006. - Vol. 40, № 1. - P. 6-11.

6.Chuchkov O. V. Transformations of the "motor end-muscle fiber" system of some rat skeletal muscles in an experiment / O. V. Chuchkov, V. I. Rastegaev, N. E. Sabelnikov // Morphology. - 2009. - P. 136, No. 4. - P. 152-156.

7.Chelnokov A. A. Functional features of reciprocal and presynaptic braking of the calf muscles in persons of different ages / A. A. Chelnokov, I. M. Tjupaev // Therapeutic physical training and sports medicine. - 2012. - No. 7. - P. 40-44. 
8. Ciavarella D. Influence of vision on masticatory muscles function: surface electromyographic evaluation / D. Ciavarella // Annali di Stomatologia. - 2014. - Vol. 2. - P. 61-65. https://doi.org/10.11138/ads/2014.5.2.061

9. Dedov I. I. Diabetes mellitus is a dangerous challenge to the world community / I. I. Dedov // Bulletin of the Russian Academy of Medical Sciences. - 2012. -T. 67, No. 1. - P. 7-13. DOI: 10.15690 / vramn.v67i1.103

10. Electronic resource Unified clinical protocol of emergency, primary, secondary (specialized), tertiary (highly specialized) medical aid. Type 1 diabetes mellitus. Kyiv 2013 Mode of access: http://moz.gov.ua/docfiles/proect_unkp1_13112013.pdf

11. Fedorin V. V. Participation of N-cholinergic receptors of the neuronal type in the regulation of the mediator secretion in the neuromuscular synapses of the mouse: autoref ... .mk.n .: Specialty 03.00.13 Normal physiology / V.V. Fedorin // - Moscow, 2008. 19 p.

12. Farkhutdinov A. M. Effect of exogenous ATP on the contractile function and the state of the postsynaptic membrane of isolated skeletal muscle of the mouse. / A. M. Farkhutdinov, S. N. Grishin, A. Yu. Teplov // Medical bulletin of Bashkortostan. 2009. - T. 4, No. 2. - P. 189 -192.

13. King J. D. Osmotic demyelination syndrome / J. D. King, M. H. Rosner // Am J. Med. Sci. - 2010. - Vol. 339, № 6. - P. $561-567$.

14. Khachayants N. Yu. Diabetic polyneuropathy / N.Yu. Khachayants // Progress in modern natural science. - 2015. - No. 3. - P. 87-92.

15. Levitsky V. A. Condition of the muscles of the tongue and its peripheral neuromuscular apparatus under experimental streptozotocin diabetes mellitus / V. A. Levitsky, O. V. Atamanchuk // Journal of the Grodno State Medical University. - 2014. Issue. 46. - P. 70-74.

16. Neretin V. Ya. Clinico-electroneurophysiological study of the state of the neuromuscular system in patients with diabetes mellitus I and II types / V. Ya. Neretin, S. V. Kotov, L. V. Petina // Journal. neurology and psychiatry by S.S. Korsakova. - 1997. - T. 97, № 2. - P. 34-38.

17. Macharia R. Neuromuscular junction morphology, fiber-type proportions, and satellite-cell proliferation rates are altered in myod-/- mice / R. Macharia, A. Otto, P. Valasek [et al.] // Muscle and Nerve. - 2010. - Vol. 42, № 1. - P. 38-52.

18. Patel K. P. Newer approaches in the treatment of diabetes mellitus / K.P. Patel, H. M. Joshi, F. D. Majmudar [et al.] // NHL Journal of Medical Sciences - 2013 Vol. 2 Issue 1 P. 6-11.

19. Pak S. V. Current state and prospects of further studies of salivary glands in the context of diabetes mellitus / S. V. Pak, S. I. Cherkashin // Clinical dentistry. - 2011. - No. 1-2. - P. 47-52.

20. Polyakova V. V. Peculiarities of the influence of taurine and glycine on the organism of rats for aloxane-induced diabetes mellitus / V. V. Polyakova, N. M. Danchenko, S. P. Veselsky // Medical Chemistry. - 2013. - № 1. - P. 30-33.

21. Shvets M. I. Dehydration: diagnostics and therapeutic tactics / N. I. Shvets, T. M. Benz, O. I. Loginchuck // Journal. Of a practical doctor. - 2006. - No. 4. - P. 21-26.

22. Shin Y. Kim Gestational Diabetes Mellitus and Risk of Childhood Overweight and Obesity in Offspring: A Systematic Review / Shin Y. Kim, J. Lucinda England, J. Andrea Sharma, Terry Njoroge // Experimental Diabetes Research - 2011 http://www.hindawi.com/journals/jdr/2011/541308/

23. Yanshina E. N. Syndrome of increased neuromuscular excitability in vibration sickness and dehydration / E. N. Yanshina, P. N. Lyubchenko, N. P. Yanshin [et al.] // Occupational medicine and industrial ecology. - 2004. - No. 7. - P. 18-20.

24. Usmanova S. N. Histochemical characteristics of the region of the neuromuscular synapse of some skeletal muscles of the head and neck: Autoref ... .kb.n .: Specialty 14.00.02 Human and Animal Anatomy / S.N. Usmanova // - Ufa, - 2006. - 19 p.

25. Vasin A. L. The role of calcium channels of different types in the regulation of quantum secretion in neuromuscular synapses of the mouse and frog: Autoref .: Specialty 03.03.01 Comparative physiology / A.L. Vasin // - Kazan, - 2010. -20 p.

26. Zak K. P. Immunity in children with diabetes mellitus / K. P. Zak, T. N. Malinovskaya, N. D. Tronko // Kiev: / Book plus, 2012. - $111 \mathrm{p}$.

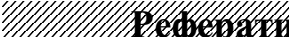

\section{МОРФОФУНКЦІОНАЛЬНЫ ЗМІНИ \\ НЕЙРОМ'ЯЗОВИХ КОНТАКТЫВ ЖУВАЛЬНИХ М'ЯЗІВ У ПІЗНІХ СТАДІЯХ РОЗВИТКУ СТРЕПТОЗОТОЦИНОВОГО ДІАБЕТУ}

Жураківська О.Я., Град А. О., Попель С. Л., Заяць

I. Т., Криницька I. Я., Марущак М. І., Дзецюх Т. I. Робота присвячена дослідженню морфофункціональних змін нейром'язових з'єднань (НМЗ) та їхного гемомікроциркуляторного русла при стрептозотоциновому цукровому діабеті (СЦД). Використали гістологічний та електронномікроскопічний методи дослідження. Встановлено, що СЦД на 56-70 добу перебігу призводить до деструкції більшості НМ3, що морфометрично виражається в зменшення їхньої площі. В еферентних претермінальних нервових волокнах відбувається атрофія аксонів та часткова дегенерація мієлінової оболонки. На ультраструктурному рівні спостерігається порушенням тонкої архітектоніки нейром'язових синапсів, а саме, зменшення: площі, довжини синаптичного контакту, кількісті синаптичних пухирців, кількості складок засинаптичної перетинки та відстані між ними. Такі зміни в НМЗ відбуваються на тлі розвитку діабетичної мікроангіопатії $\mathrm{i}$, як наслідок, призводять до порушення провідності нервових волокон у

\section{МОРФОФУНКЦИОНАЛЬНЫЕ ИЗМЕНЕНИЯ} НЕЙРОМЫШЕЧНЫХ КОНТАКТОВ ЖЕВАТЕЛЬНЫХ МЫШЦ В ПОЗДНИХ СТАДИЯХ РАЗВИТИЯ СТРЕПТОЗОТОЦИНОВОГО ДИАБЕТА Жураковская А.Я., Град А. А., Попель С. Л., Заяц И. Т., Криницкая И. Я., Марущак М. И., Дзецюх Т. И. Работа посвящена иследованию морфофункциональных изменений нейромышечных соединений (НMC) и их гемомикроциркуляторного русла при стрептозотоциновом сахарном диабете (ССД). Использовали гистологический и электронномикроскопический методы исследования. Установлено, что ССД на 56-70 сутки течения приводит к деструкции большинства НMC, что морфометрически выражается в уменьшении их площади. В эфферентных претерминальных нервных волокнах происходит атрофия аксонов и частичная дегенерация миелиновой оболочки. На ультраструктурном уровне наблюдается нарушением тонкой архитектоники нейромышечных синапсов, а именно, уменьшение: площади, длины синаптического контакта количеству синаптических пузырьков, количеством складок засинаптической перепонки и расстоянием между ними. Такие изменения в НМС происходят на фоне развития диабетической микроангиопатии и, как следствие, приводят к нарушению проводимости нервных волокон в жевательной мышце и 
жувальному м'язі та збудливості м'язових волокон, що підтверджується даними електронейроміографії ЕНМГ. За даними ЕНМГ при тривалості експериментального цукрового діабету 56-70 діб аксональна полінейропатія була виявлена у 6 тварин, інші 4 мали аксонально-демієлінізуючу полінейропатію. При цьому тільки у 9,5 \% випадків зменшується тривалість потенціалів рухової одиниці, але у 64,5 \% випадків понижується амплітуда осциляцій $(p<0,05)$, що свідчить про швидкі темпи деструкції НМ3 при декомпенсованому експериментальному ЦД.

Ключові слова: нейром'язові з'єднання, жувальний м'яз, стрептозотоциновий цукровий діабет.

Стаття надійшла 25.08.2017 p. возбудимости мышечных волокон, что подтверждается данными электронейромиография ЭНМГ. По данным ЭНМГ при продолжительности экспериментального сахарного диабета 56-70 суток аксональная полинейропатия была обнаружена в 6 животных, остальные 4 имели аксональное-демиелинизирующую полинейропатию. При этом только в 9,5\% случаев уменьшается продолжительность потенциалов двигательной единицы, но в $64,5 \%$ случаев снижается амплитуда осцилляций ( быстрых темпах деструкции НМС при декомпенсированном экспериментальном СД.

Ключевые слова: нейромышечные соединения, жевательная мышца, стрептозотоциновый сахарный диабет.

Рецензент Волков К.С.

DOI 10.26724 / 2079-8334-2017-3-61-114-119 УДК 616.361-007.272:616.37:616-005

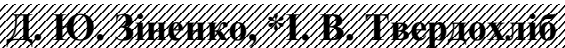

2. SAm

\section{УЛЬТРАСТРУКТРНІ ЗМІНИ ГЕМОМІКРОЦИРКУЛЯЦІї ТА ПАРЕНХІМИ ПІДШЛУНКОВОЇ ЗАЛОЗИ ПРИ РОЗВИТКУ ЕКСПЕРИМЕНТАЛЬНОГО ГОСТРОГО ПАНКРЕАТИТУ У ЩУРІВ}

e-mail: ivt@dsma.dp.ua

У роботі були досліджені ультраструктурні зміни мікроциркуляторного русла та паренхіми підшлункової залози щурів у моделях гострого панкреатиту після введення L-аргініну та таурохолату натрію в різних дозах. За допомогою трансмісійної електронної мікроскопії виявлено загальні ранні ознаки розвитку панкреатиту: 1) деформація та деструкція стінки артеріол; 2) гіпоксичне ушкодження фенестрованого ендотелію гемокапілярів панкреатичних острівців і судин інсуло-ацинарної портальної системи; 3) сладжування еритроцитів і тромбоз соматичних гемокапілярів у складі панкреатичних ацинусів 3 ендотеліальною фрагментацією; 4) дилятація та спустошення дренажної ланки мікроциркуляторного русла. Встановлено, що ступінь ушкодження гемомікроциркуляції залежить від дози L-аргініну або таурохолату натрію, що у подальшому визначає рівень паренхіматозних порушень, а також характер і темпи компенсаторно-пристосувальних або деструктивних змін у складі підшлункової залози.

Ключові слова: підшлункова залоза, моделі гострого панкреатиту, щури, мікроциркуляція, ультраструктура.

Робота є фрагментом НДР „Аналіз нормального й аномального гістогенезу тканинних компонентів сериевосудинної системи людини та експериментальних тварин” (номер держсавної реєстрації 0115U007837).

Після створення моделей гострого панкреатиту за допомогою різних речовин, що підсилюють секрецію залози [10], чинять токсичну або місцеву активуючу дію [7, 8], у багатьох дослідженнях було доведено їх дозозалежний ефект. Особливу увагу привернули питання про роль мікроциркуляторних змін у розвитку пристосувально-компенсаторних або деструктивних процесів у залежності від глибини патоморфологічних перебудов підшлункової залози $[1,2,3,6$, 11]. Проте, дотепер не було здійснено комплексного морфологічного дослідження різних моделей панкреатиту з урахуванням паренхіматозних змін у залозі, стану мікроциркуляції в органі та їх взаємодії на ультраструктурному рівні.

Метою роботи було виявити ранні ультраструктурні зміни мікроциркуляторного русла в підшлунковій залозі при експериментальному гострому панкреатиті.

Матеріал та методи дослідження. Статевозрілі щури-самці лінії Wistar (вага 150-200 г) утримувалися при звичайних умовах (вільний доступ до їжі й води, температура повітря $22-24^{\circ} \mathrm{C}$ ). Використовували дві моделі гострого панкреатиту. У першій моделі після нічного голодування щурам одноразово інтраперитонеально вводили розчин L-аргініну в дозах 3 г/кг 4 г/кг і 5 г/кг у 0,2 мл фізіологічного розчину в ліву нижню частину черевної порожнини. Для контрольних тварин використовували відповідний об'єм фізіологічного розчину. Експеримент виконувався згідно 3 рекомендаціями С.H. Kubisch зі співавторами [9]. Для реалізації другої моделі гострого панкреатиту проводили загальне знеболювання за допомогою ін'єкції розчину кетаміна в дозі 100 мг/кг. Після серединної лапаротомії здійснювали фіксацію дванадцятипалої кишки й накладали лігатуру на загальну жовчну протоку. Ін'єкцією через антимезентеричний край дванадцятипалої 